\title{
ハライド熱還元法による粉末チタンの製造†
}

\author{
宇田哲也地岡部徹 早稲田嘉夫
}

東北大学素材工学研究所素材再生プロセス研究センター

J. Japan Inst. Metals, Vol. 62, No. 9 (1998), pp. 796-802

\section{Titanium Powder Production by Halidothermic Reduction ${ }^{\dagger}$}

\author{
Tetsuya Uda", Toru H. Okabe and Yoshio Waseda
}

Research Center for Metallurgical Process Engineering, Institute for Advanced Materials Processing,

Tohoku University, Sendai, 980-8577

\begin{abstract}
Instead of the conventional metallic reductant, halide salt has been tested as a reductant for producing titanium powder directly from $\mathrm{TiCl}_{4}$. Using various thermodynamic data, $\mathrm{DyCl}_{2}$ was found to be suitable for the halidothermic reduction of $\mathrm{TiCl}_{4}$. When $\mathrm{TiCl}_{4}$ was fed into $\mathrm{DyCl}_{2}$ single salt or $\mathrm{DyCl}_{2}$ containing molten salts at $1073 \mathrm{~K}$, fine titanium powder of several ten micron meters in diameter was obtained. In contrast to the sponge titanium produced by the conventional Kroll process, the present new process using halidothermic reduction appears to hold promise in reducing difficulties by making titanium powder without precipitation of sponge titanium on the metallic container. From the thermodynamic point of view, the resultant $\mathrm{DyCl}_{3}$ can be reduced to $\mathrm{DyCl}_{2}$ by magnesium. These particular features enable us to give possibility of the production of titanium powder directly from $\mathrm{TiCl}_{4}$ as well as the development of a new continuous titanium reduction process by adding reaction mediator in the Kroll process.
\end{abstract}

(Received April 6, 1998; In Final Form June 29, 1998)

Keywords: titanium, Kroll process, metallothermic reduction, electrochemistry, continuous process, powder production, rare earth chlorides, dysprosium chloride

\section{I. 緒言}

現在, チタン、ニオブ，タンタルなどのレアメタルは，活 性金属 $(\mathrm{Mg}, \mathrm{Al}, \mathrm{Na}$ 等) 還元剤とする金属熱還元法(metallothermic reduction)によりその汪とんどが生産されてい る(1)(2). 例光ば，チタンは四塩化チタン $\left(\mathrm{TiCl}_{4}\right)$ のマグネシ ウム熱還元法 (クロール法(3)(4) )で製造されているが, 生成し たチタンは反応壁からスポンジ状に析出し, 反応容器壁に固 着する、したがって, 生成チタンの連続的な分離・回收が困 難であり，バッチ式プロせスの採用を余義なくされて抢り生 産效率の向上は難しい(5)。 また, チタンの連続生産法の確立 を目的とした過去の研究でもチタンの反応容器壁への固着が 大きな問題となり，いずれの場合它実用化には至っていな い(6)(7).ただし，還元された生成チタンが粉末状であれば， 反応容器壁への固着が低減でさると考光られる。一方, 現在 粉末冶金用のチタンはクロール法によって製造したスポンジ チタンを原料としてがスアトマイズ法(8)，ならびに水素化粉

†新しい概念炕よるチタン塩化物の金属熱還元関する基礎的 研究 $(\mathrm{N})$

计東北大学大学院生 (日本学術振興会特別研究員) (Graduate Student, Tohoku University (Research Fellow of the Japan Society for the Promotion of Science))
砕法(9)などルより生産されているが，效果的な粉末チタンを 直接製造できる新しい方法の確立が望れれかつ期待されてい る.

著者らは, 最近, 電気化学的な反応几着目し,クロール法 に扮けるチタンの還元メカニズムの解析を試み，原料と還元 剤が物理的に接触しなくても，導電体を介した反応(EMR: Electronically Mediated Reaction)により, 還元反応が進行 することを実証し，その幅広い応用性を明らかにした(10)-(13).

このEMRという概念を導入すると，金属熱囬元反応は， 反応生成物であるイオン性融体抏よび金属を反応媒体とす る, 活性金属と原料の電気化学的な酸化還元反応と見なすこ とができる。な，金属熱還元反応に持ける析出物の形態や 反心部位は，電子ならびにイオンの移動経路に大きく低存 し，均一反応の条件さえ設定できれば粉末状のチタンを直接 製造できる可能性が判明した(11).

ハライド塩には融体中で複数の価数をとり，低級塩の中に はそれ自体が強い還元力を有する場合があるので，金属では なくハライド塩を還元剤として金属を製造することも原理的 には可能である.さらにこのような還元力を有するハライ ド塩を含さイオン性融体中で還元反応を進行させることは, 均一反応滴して物り，粉末状の金属学効率上く生成できる 可能性もめる。しかし, 過去に金属ではなくハライド塩を還 
元剤として利用し，チタンなどのレアメタル粉末を製造した 例は著者らの知る限り報告されていない。このような現状分 析を踏まえ, 本研究では八ライド塩により $\mathrm{TiCl}_{4}$ を還元し, 粉末状チタンを直接製造する新しい方法の検証を試みた.

\section{II. 実 験 原 理}

\section{1. ハライド熱還元法}

原料(MX)の還元を金属で行う式(1)に示す反応を利用す る場合を金属熱還元法というが，ハライド熱還元法とは式 （2）に示すよらに低級ハライド塩を還元剂とする場合である.

$$
\begin{aligned}
& \mathrm{MX}+\mathrm{R}=\mathrm{M}+\mathrm{RX} \\
& \mathrm{MX}+\mathrm{RX}_{n}=\mathrm{M}+\mathrm{RX}_{n+1}
\end{aligned}
$$

本研究では反応系を塩化物に限定し $\mathrm{TiCl}_{4}$ の還元実験を行 った.チタンイオンは塩化物浴中に特いて, $4+, 3+, 2+$ の価数をとるため, 元素 R のハライド塩による還元反応は 式(3)のように記述できる.

$$
\begin{aligned}
& \mathrm{Ti}^{4+}+\mathrm{R}^{2+} \longrightarrow \mathrm{Ti}^{3+}+\mathrm{R}^{3+} \\
& \mathrm{Ti}^{3+}+\mathrm{R}^{2+} \longrightarrow \mathrm{Ti}^{2+}+\mathrm{R}^{3+} \\
& \mathrm{Ti}^{2+}+2 \mathrm{R}^{2+} \longrightarrow \mathrm{Ti}(\mathrm{s})+2 \mathrm{R}^{3+}
\end{aligned}
$$

ここでは, 式を簡略化するために塩素イオンを省略し, 低級 ハライド塩の酸化数を 2 , 酸化雾囲気で安定なハライド塩の 酸化数を 3 とした．この反応で注目すべき点は，目的生成 物の金属チタン以外の反応化学種はすべて融体中のイオンで あることにある。また， $\mathrm{Mg} / \mathrm{Mg}^{2+}$ に対する $\mathrm{Ti}^{2+} / \mathrm{Ti}^{3+}$ ，特 よび $\mathrm{Ti}^{3+} / \mathrm{Ti}^{4+}$ の標準電極電位 $\left(E_{\mathrm{Ti}^{2+} / \mathrm{Ti}^{3+}}^{\circ}=0.93 \mathrm{~V}^{(14)}\right.$, $\left.E_{\mathrm{Ti}^{3+} / \mathrm{Ti}^{4^{+}}}^{\circ}=0.98 \mathrm{~V}^{(14)}\right)$ は $\mathrm{Ti} / \mathrm{Ti}^{2+}$ の標準電極電位 $\left(E_{\mathrm{T}_{\mathrm{i}} / \mathrm{Ti}^{2^{+}}}^{\circ}=\right.$ $\left.0.67 \mathrm{~V}^{(14)}\right)$ に比べて高いので，本研究に特いてチタンの還元 反応を熱力学的に考察する際のチタンイオンは $\mathrm{Ti}^{2+}$ と考学 て差し支えない。また，厳密には反応化学種の活量も考慮し なければならないが，本研究では原料ならびに還元剤が多量 に存在する場合を想定しているので，標準電極電位における 反応の進行方向について検討する。

このような場合, 還元剤 $\mathrm{R}^{2+}$ によるチタンの還元反応, すなわち式(3c)の反応が右に進行するためには, $\mathrm{R}^{2+} / \mathrm{R}^{3+}$ 平衡の標準電極電位 $\left(E_{\mathrm{R}^{2+} / \mathrm{R}^{3+}}^{\circ}\right)$ が, $\mathrm{Ti} / \mathrm{Ti}^{2+}$ 平衡で決まる標準 電極電位より低くなければならない。

$1073 \mathrm{~K}$ に打いて金属チタンと共存可能な塩化物はアルカ リ金属, アルカリ土類金属, ならびに希土類金属の塩化物が 知られているが，アルカリ金属扣よび，アルカリ土類金属の 塩化物は，一般的にはそれぞれ 1 価もしくは 2 価の状態の みで存在し還元力のある低級塩が存在しない(14). そこで本 研究では複数の価数を取りらる希土類金属の塩化物に注目 しまず啇切な還元剤の選択を検討した。

\section{2. 希土類塩化物の標準電極電位}

希土類塩化物は, 多くの場合, $\mathrm{RECl}_{3}(\mathrm{RE}=$ Rare Earth element)が安定塩として知られているが, 中には低級塩化 物も安定なものがある. 特に, 一部の元素では, 2 塩化物
$\left(\mathrm{RECl}_{2}\right)$ の存在が広く知られているが, $\mathrm{RECl}_{2}$ は $\mathrm{RECl}_{3}$ の 場合 ${ }^{(14)}$ とは異なり, その熱力学的性質(生成の Gibbs エネル ギー変化等)は, $\mathrm{SmCl}_{2}, \mathrm{YbCl}_{2}$ 以外不明な点が多い.

Polyachenok と Novikov ${ }^{(15)}$ ，ならびに Johnson ${ }^{(16)}$ は, 希 土類金属の 2 塩化物に関して，Born-Haber cycleを用いて

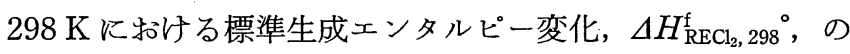

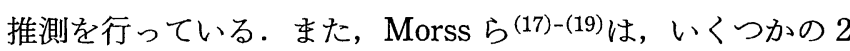
塩化物に関して, 希 $\mathrm{HCl}$ 溶液への溶解に伴う熱量測定を行 い $\Delta H_{\mathrm{RECl}_{2}, 298^{\circ}}^{\mathrm{f}}$ 求めている.さらに, 最近では, Goryushkin ${ }^{(20)}$ が起電力測定によって，一部の $\mathrm{RECl}_{2}$ の熱力 学的安定性を評価している.これらの研究結果に打いて, Johnson の推測値 ${ }^{(16)}$ の妥当性が示された. そこで, 本研究

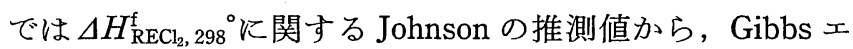
ネルギー関数(Agef)を用いて，1073 Kに特ける $\mathrm{RECl}_{2}$ の 標準生成の Gibbs エネルギー変化， $\Delta G_{\mathrm{RECl}_{2}}^{\mathrm{f}}$ ，を見積もり， この值から $E_{\mathrm{RE}^{2+} / \mathrm{RE}^{3+}}^{\circ}$ v $\mathrm{Mg} / \mathrm{Mg}^{2+}$ ならびに $E_{\mathrm{RE} / \mathrm{RE}^{2+}}^{\circ}$ vs $\mathrm{Mg} /$ $\mathrm{Mg}^{2+}$ を計算した. この計算結果を Fig. 1 に示す.ただし， $\mathrm{ScCl}_{2}, \mathrm{YCl}_{2}$ ならびに $\mathrm{LuCl}_{2}$ の $298 \mathrm{~K}$ の標準生成エンタルピ 一には, Johnsonの推測值がないので Polyachenok と Novikov の推測値を用いた. 物 $(\mathrm{La} \sim \mathrm{Eu})$ には $\mathrm{SmCl}_{2}$ の報告値 $\left(-157 \mathrm{~J} / \mathrm{K} \cdot \mathrm{mol}^{-1}\right)$ を, 一 方, 重希土類の 2 塩化物 $(\mathrm{Gd} \sim \mathrm{Lu})$ 飞は $\mathrm{YbCl}_{2}$ の報告值 $\left(-140 \mathrm{~J} / \mathrm{K} \cdot \mathrm{mol}^{-1}\right)$ を用いた。さらに，1073 K 以下で融点 もしくは相変態が知られている $\mathrm{RECl}_{2}$ に関しては， Goryushkin ${ }^{(21)}$ にってDTA を用いて測定されている相変 態に伴らェンタルピー変化 $\left(\Delta H_{\mathrm{m}}, \Delta H_{\mathrm{Tr}}\right)$ を用い，標準状態 の変換を行った.

希土類塩化物の 2 塩化物が安定に存在するための条件は, 2 価 $/ 3$ 価の標準電極電位 $\left(E_{\mathrm{RE}^{2+} / \mathrm{RE}^{3+}}^{\circ}\right)$ が 0 価 $/ 2$ 価の標準電極 電位 $\left(E_{\mathrm{RE} / \mathrm{RE}^{2+}}^{\circ}\right)$ よりも高い必要があり, 安定に存在する 2 塩 化物は, Fig. 1から Nd, Sm, Eu, Dy, Ho, Tm, ならびに $\mathrm{Yb}$ のみであることが推測される。ここで, Ho を除いては実験 的に $\mathrm{RECl}_{2}$ の存在が確認されている(22).な拈 Ho に関して

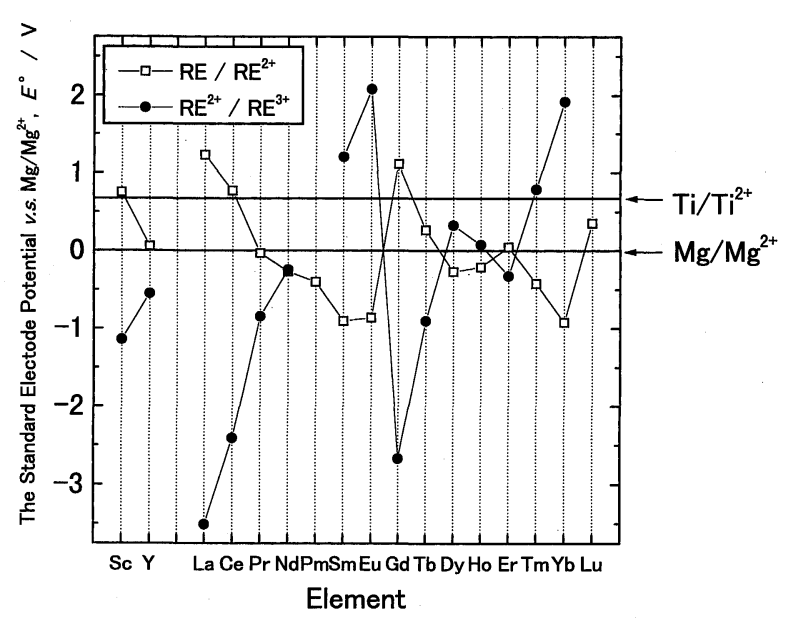

Fig. 1 The calculated standard electrode potentials of rare earth chlorides at $1073 \mathrm{~K}$. 
は $\mathrm{HoCl}_{2}$ ではなく $\mathrm{Ho}_{5} \mathrm{Cl}_{11}$ が実験的に知られておりこれ は 2 価と 3 価の Ho イオンの複塩化物と考觉られている(22).

7 種類の 2 塩化物のうち $E_{\mathrm{RE}^{2+} / \mathrm{RE}^{3+}}^{\circ}$ が $E_{\mathrm{T} / / \mathrm{T}^{2+}}^{\circ}$ より低く, チ タン塩化物を金属チタンまで還元可能なるのは，Fig. 1 によ り $\mathrm{NaCl}_{2}, \mathrm{DyCl}_{2}$ ならびに, $\mathrm{HoCl}_{2}\left(\mathrm{Ho}_{5} \mathrm{Cl}_{11}\right)$ であ. 最近, 著者らは $1073 \mathrm{KK}$ K小て $\mathrm{DyCl}_{2}-\mathrm{MgCl}_{2}$ 鼬合塩と金属マグ ネシウムの相平衡が達成すること, さらには, ジスプロシウ ムが多価イオンであるため誤差が大さいが，1073 Kに和々 る $\mathrm{DyCl}_{2}$ の分解電压は $2.6 \mathrm{~V}$ 程度であり，これは， $E_{\mathrm{Dy}^{2+} / \mathrm{Dy}^{3+}}^{\circ}$ $=0.1 \mathrm{~V}\left(v s \mathrm{Mg} / \mathrm{Mg}^{2+}\right), E_{\mathrm{D} y / \mathrm{Dy}^{2+}}^{\circ}=-0.1 \mathrm{~V}\left(\right.$ vs $\left.\mathrm{Mg} / \mathrm{Mg}^{2+}\right) 飞$ 相 当することを明らかにし(23)，Fig. 1 亿示すジスプロシウム 塩化物に関する計算が妥当であることを確認した。そこで, 本研究では $\mathrm{DyCl}_{2}$ を用いたチタン塩化物の還元反応を実証 する実験を行った。

\section{III. 実 験 方 法}

\section{1. $\mathrm{DyCl}_{2}$ の作成}

高純度の $\mathrm{DyCl}_{2}$ 試薬の入手が困難であるため，本研究で

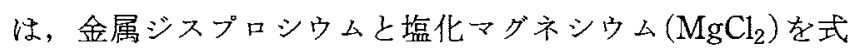
(4)により $1073 \mathrm{~K}$ に拈いて反応させることにより $\mathrm{DyCl}_{2}$ を 作製した.

$$
\operatorname{Dy}(\mathrm{s})+\mathrm{MgCl}_{2}(1)=\mathrm{DyCl}_{2}(1)+\mathrm{Mg}(1)
$$

実験に用いた試薬の公称䋘度牤よび形熊をTable 1 火示 于.

具体的には，金属ジスプロシウム， $\mathrm{MgCl}_{2}$ ならびに金属 マグネシウムを充填した軟鋼製密閉容器をアルゴン気流中に 設置し，1073 Kに拈いて約 $86 \mathrm{ks}$ 間保持し反応させ， $\mathrm{DyCl}_{2}$ を合成した。金属ジスプロシウムは $\mathrm{MgCl}_{2}$ を睘元す るのに必要な化学量論の1.2倍量を系内に設置した。あらか じめ金属マグネシウムを密閉容器内に設置したのは, 程相と 金属相の分離を促進するためである. 区応後，軟鋼製密閉容 器ごと氷冷し, 塩相と金属相を機械的に分離し, 塩を回収し た。回収した試料は，誘導プラズマ発光分析装置(ICP)を用 いてジスプロシウム，マグネシウム濃度測定，ならびに硝酸 銀を用いた重量法により塩素濃度測定を行った。

\section{2. $\mathrm{TiCl}_{4}$ 還元実験装置および手順}

実験装㯰の基本構成は，電気炉内に設置したステンレス製 の密封容器, 雾囲気制御装置, アルゴンガス供給装置,

Table 1 Purity and form of reagents used in this study.

\begin{tabular}{lcl}
\hline \hline Reagent & Purity (mass\%) & \multicolumn{1}{c}{ Notes } \\
\hline $\mathrm{Dy}$ & $98.9^{*}$ & Lump, Oxygen $\leqq 0.2$ mass $\%$ \\
$\mathrm{Mg}$ & 99.9 & Ingot \\
$\mathrm{MgCl}$ & 98.8 & Flake, Moisture $\leqq 3$ mass $\%$ \\
$\mathrm{NaCl}$ & 99 & Powder \\
$\mathrm{KCl}$ & 99 & Powder \\
$\mathrm{TiCl}_{4}$ & 99 & Liquid \\
\hline
\end{tabular}

* excluding gaseous element
$\mathrm{TiCl}_{4}$ 供給装置, ならびルガス排気装置からなっている。密 封容器内にはFig. 2 K示すよう以軟鋼製坩堝(内径 $84 \mathrm{~mm}$ もしくは $48 \mathrm{~mm}$ ) を設置した。

聿堝内には, $\mathrm{DyCl}_{2}$ 単塩, 屯しくは, 混合塩 $\left(\mathrm{MgCl}_{2}\right.$ $\mathrm{DyCl}_{2}$ ，ならびに NaCl-KCl-DyCl 2$)$ を充填し, 真空下 $(2 \mathrm{~Pa}$ 程度)で $573 \mathrm{~K}$ に約 $40 \mathrm{ks}$ 保持した。坩堝内温度を $1073 \mathrm{~K}$ に上昇し，温度が一定になるのを確認した後， $\mathrm{TiCl}_{4}$ の供給 を開始した。 $\mathrm{TiCl}_{4}$ は Fig. 2 に示すように軟鋼製(直径 12 $\mathrm{mm}$, 長さ $800 \mathrm{~mm}$ ) $の \mathrm{TiCl}_{4}$ 供給管を密閉容器上部中央から 挿入し，铛量液送ポンプを用いて液体 $\mathrm{TiCl}_{4}$ を一定速度で供 給した。な拉，供給速度は， $\mathrm{TiCl}_{4}$ 容器の質量変化加ら算出 した. カソード管内には, $5 \times 10^{-7} \mathrm{~m}^{3} / \mathrm{s}\left(30 \mathrm{~cm}^{3} / \mathrm{min}\right)$ 程度 のアルゴンガスを供給することにより, 坩堝内の溶融塩の擋 䢁を促進し，同時に析出物によるカソード管の目詰をりを防 止する工夫をした。 また，生成したチタン粉末を回収するた め, Fig. 2 に示すよ5に軟鋼製の粉末回収血を $\mathrm{TiCl}_{4}$ 供給管 の直下に配置した．さらに，本研究ではイオン性融体中の還 元反応を均一に進行させることが目的のため，金属導電体を 介した反応(10)(12) (LR-EMR: Long Range-EMR)を可能な限 り防ぐ必要がある，したがって， $\mathrm{TiCl}_{4}$ 供給管ならびに熱電 対保護管, 粉末回收血, ならびに㖏堝はそれぞれ電気的に絶 縁する工夫を施し実験を行った。

Table 2 K溶融塩の初期組成, 供給した $\mathrm{TiCl}_{4}$ の質量 $\left(w_{\text {feed }} / \mathrm{g}\right), \mathrm{TiCl}_{4}$ 供給速度 $\left(\mathrm{V}_{\mathrm{TiC}_{4}}\right)$ などの実験条件飞関する代 表的な值ををとめて示す。な拈，還元反応を十分に進行させ るために $\mathrm{DyCl}_{2}$ は $\mathrm{TiCl}_{4}$ の還元に必要な量の約 $2.5 〜 3.6$ 倍量

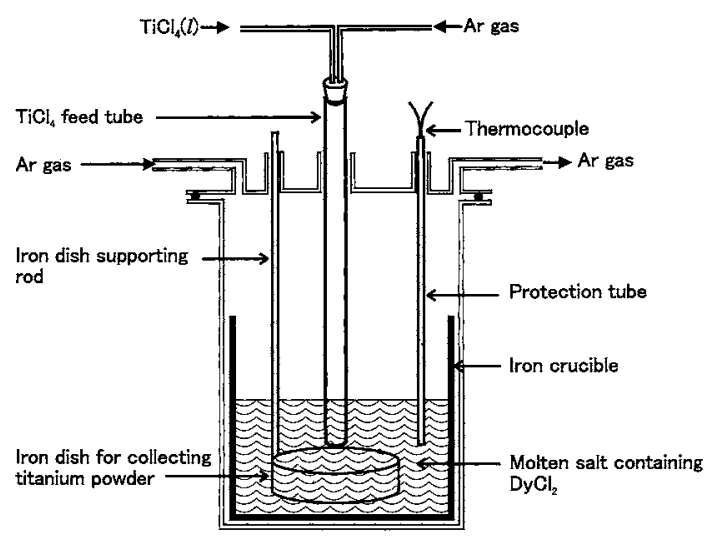

Fig. 2 Experimental setup for $\mathrm{TiCl}_{4}$ reduction by $\mathrm{DyCl}_{2}$.

Table 2 Experimental conditions in this study.

\begin{tabular}{|c|c|c|c|c|}
\hline Exp. & $\begin{array}{l}\text { Composition } \\
\text { of salt } \\
\text { (mol\%) }\end{array}$ & $\begin{array}{l}\text { Amount of salt } \\
w_{\text {salt }} / g\end{array}$ & $\underset{w_{\text {feed }} / \mathrm{g}}{\text { Amount of }} \mathrm{TiCl}_{4}$ & $\begin{array}{l}\mathrm{TiCl}_{4} \text { feed rate } \\
v_{\mathrm{TiC}} / \mathrm{mg} \cdot \mathrm{s}^{-1}\end{array}$ \\
\hline A & $\mathrm{DyCl}_{2}$ & 448 & 25.3 & 3.9 \\
\hline B & $\begin{array}{l}\mathrm{NaCl}-44.4 \mathrm{KCl}- \\
11.3 \mathrm{DyCl}_{2}\end{array}$ & 1078 & 25.4 & 2.8 \\
\hline C & $\begin{array}{l}\mathrm{MgCl}_{2-}^{-} \\
28.7 \mathrm{DyCl}_{2}\end{array}$ & 653 & 19.8 & 4.7 \\
\hline
\end{tabular}




\section{を充填した。}

$\mathrm{TiCl}_{4}$ 供給終了後は, 坩堝内に設置した粉末回収皿を溶融 塩上に引き上げ，アルゴン気流中で約 $40 \mathrm{ks}$ かけて反応容器 ごと炉冷した。試料は熱水もしくは，希塩酸を用いて溶融塩 の溶出を繰り返し行い析出物を回収した。得られた析出物 は，虽光 $\mathrm{X}$ 線分析 $(\mathrm{XRF})$ により元素分析を行った後，X線 粉末回折(XRD)により相の同定を行い，析出物の形態を走 查型電子顕微鏡(SEM)で観察した。

\section{N. 実 験 結 果}

\section{1. $\mathrm{DyCl}_{2}$ 作成結果}

金属ジスプロシウムと $\mathrm{MgCl}_{2}$ を $1073 \mathrm{~K}$ 淤いて反応さ せた結果，金属相が容器上部に浮かび，黒色の塩が容器下部 から回收できた，塩相の組成分析結果，拉よび塩相に和ける 塩素とジスプロシウムの mol 比を Table 3 汇示す。表から 明らかなように，塩相におけるマグネシウム濃度は，0.5〜 $0.6 \mathrm{~mol} \%$ 程度と低く，また，これのジスプロシウムと塩素 の mol 比は約2.1であることから，得られた塩は活注 $\mathrm{DyCl}_{2}$ と考觉ることができる。この量猃比からのずれは，副生成し た $\mathrm{DyCl}_{3}$ による寄与と考光られる。生，金属相はXRF 分 析の結果， Mg-Dy 合金であり，合金中の Dy 濃度は，あら かじめ忞填した金属 $\mathrm{Mg}$ 量に依存し，4〜10 mol\%程度であ った。な扐これらの塩相と金属相に拈けるジスプロシウム の分配関係に関する詳細な実験結果については，あらためて 報告する予定である。

以下の $\mathrm{TiCl}_{4}$ の還元実験では上記の手順で作成した $\mathrm{DyCl}_{2}$ を還元凮として用いた。

\section{2. $\mathrm{DyCl}_{2}$ による $\mathrm{TiCl}_{4}$ の還元}

実験後に溶融塩上部に引き上げた粉末回収且の写真を Fig. 3 に示す，写真では判別しにくいが，死色の粉末状析 出物の堆積が確認される。粉末回収皿状火塩がほとんど観察 されなかったのは，粉末回収血を引き上げた時に未溶接部分 の穴から塩が落ちたためである。

得られた堆積物から残留塩を溶出し，灰色の粉末状析出物 を回取した。これの粉末X線回折パターンをFig. 4 に， XRF Kよる組成分析結果を Table 4 飞示す。

Table 3 Analytical results of the salt obtained after $\mathrm{MgCl}_{2}$ reduction by $\mathrm{Dy}$ at $1073 \mathrm{~K}$.

\begin{tabular}{ccccc}
\hline \multirow{2}{*}{\begin{tabular}{c} 
Run. \\
\cline { 3 - 4 }
\end{tabular}} & \multicolumn{3}{c}{ Composition (mol\%) } & Cl/Dy molar ratio \\
\hline 1 & $\mathrm{Dy}^{*}$ & $\mathrm{Cl}^{\text {T+ }}$ & $\mathrm{Mg}^{*}$ & \\
\hline 2 & 31.0 & 68.4 & 0.57 & 2.17 \\
3 & 31.6 & 67.9 & 0.56 & 2.11 \\
\hline ave. & 32.1 & 67.4 & 0.56 & 2.06 \\
\hline
\end{tabular}

* determined by ICP

* determined by gravimetric method
Fig. 4 から容易にわかるように得られた粉末状析出物は， 金属チタンである. $\mathrm{DyCl}_{2}$ 単浴あるいは $\mathrm{NaCl}-\mathrm{KCl}-\mathrm{DyCl}_{2}$ 混 合塩を用いた実験 (exp. \#A，exp. \#B)で得られた粉末析出 物は注淁チタン単相で汤ったが， $\mathrm{MgCl}_{2}-\mathrm{DyCl}_{2}$ 混合塩を用 いた実験 (exp. \#C)ではチタン以外に DyOCl 相が認められ

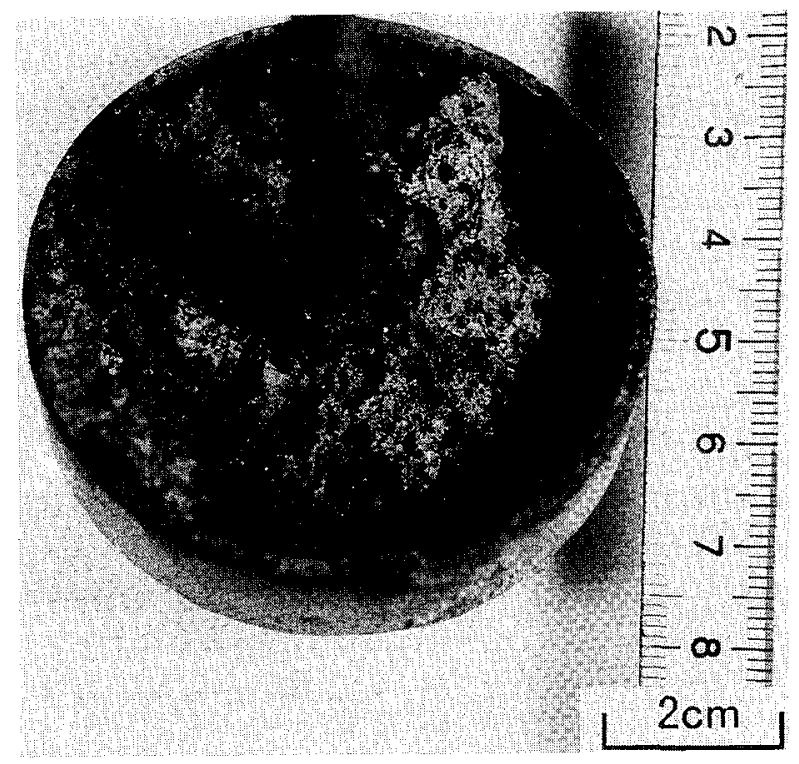

Fig. 3 Photograph of a dish after experiment (exp. \#B).

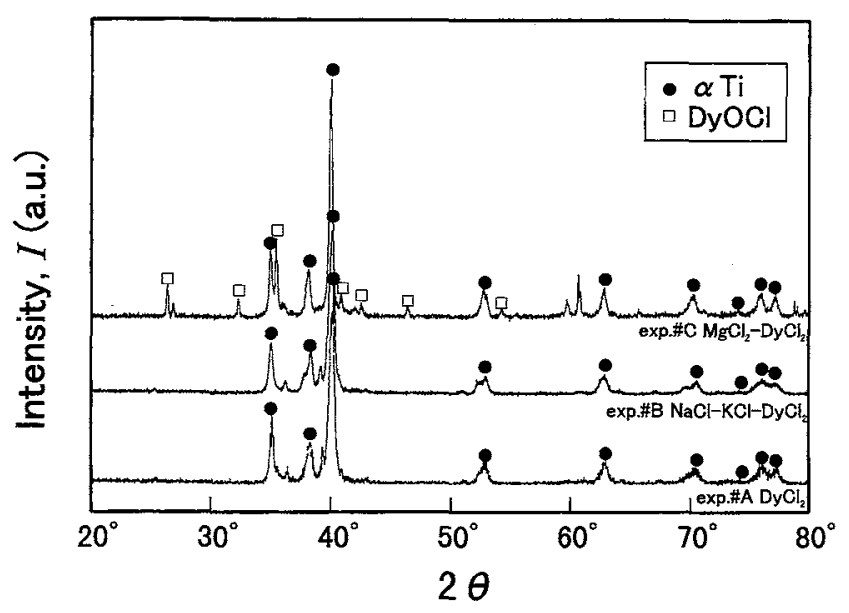

Fig. 4 X-ray diffraction patterns of the precipitate obtained in a dish.

Table 4 Analytical results of the precipitate obtained on the dish.

\begin{tabular}{llcccc}
\hline \hline \multirow{2}{*}{$\begin{array}{c}\text { Exp. } \\
\#\end{array}$} & \multirow{2}{*}{ Molten salt } & \multicolumn{4}{c}{ Composition (mass\%) } \\
\cline { 3 - 6 } & & $\mathrm{T} \mathbf{i}$ & $\mathrm{Fe}$ & $\mathrm{Dy}$ & $\mathrm{Cl}$ \\
\hline $\mathrm{A}$ & $\mathrm{DyCl}_{2}$ & 94.0 & 6.0 & trace & trace \\
$\mathrm{B}$ & $\mathrm{NaCl}_{\mathrm{KCCl}-\mathrm{DyCl}}$ & 98.0 & 1.2 & 0.7 & 0.1 \\
$\mathrm{C}$ & $\mathrm{MgCl}_{2}-\mathrm{DyCl}_{2}$ & 74.0 & 0.9 & 21.0 & 3.9 \\
\hline
\end{tabular}


た、なお，Table 4 飞示すよ5に，実験条件に依存するが装 置の構成材料として用いた鉄が不純物として検出された。

回収したチタン量について，供給量との関係を検討する。 例えば， $\mathrm{NaCl}-\mathrm{KCl}-\mathrm{DyCl}{ }_{2}$ 混合塩を用いた塞験 (exp. \#B)で は，回収血ならびに㘫堝底から得た粉末状チタンは $1.96 \mathrm{~g}$ であり，これは供給した $\mathrm{TiCl}_{4}$ 汶対して化学量論的炕生成す るチタン量 $(6.4 \mathrm{~g})$ の $32 \%$ K相当することが判明した。なお， 坦堝壁の液面付近や $\mathrm{TiCl}_{4}$ 供給管などに付着したヂンも認

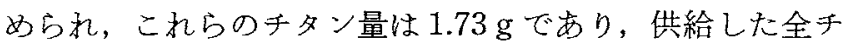
タン量の $27 \%$ に相当する。したがって，実験 (exp. \#B)にお いて回収できたチタンは，供給量に対して58\%であった。 残りのチタンは，リーチングを行っていない塩もしくは塔 壁に分散しているものと考它られる。これらのチタン粉末 が，坩堝底部もしくは粉末回収血に堆積しなかったのは，ア ルゴンガスによる溶融塩中のバブリング等が主たる要因であ ると考えられる。な拉， $\mathrm{TiCl}_{4}$ 供給管に付着したチタン $(0.63 \mathrm{~g})$ は，粉末状ではなくLR-EMRなどで得られるチタ ンと同様に金属壁に固着した堅い塊状の析出物であった。 た， $\mathrm{MgCl}_{2}-\mathrm{DyCl}_{2}$ を混合塩に用いた実験(exp. \#C) 飞执いて も実験 (exp. \#B) と同様に, 甘堝底部, チタン回收且から粉 末状チタンを， $\mathrm{TiCl}_{4}$ 供給管からこれに固着したチタンを回 収することができた。一方，還元浴に $\mathrm{DyCl}_{2}$ 単浴を用いた

(a)

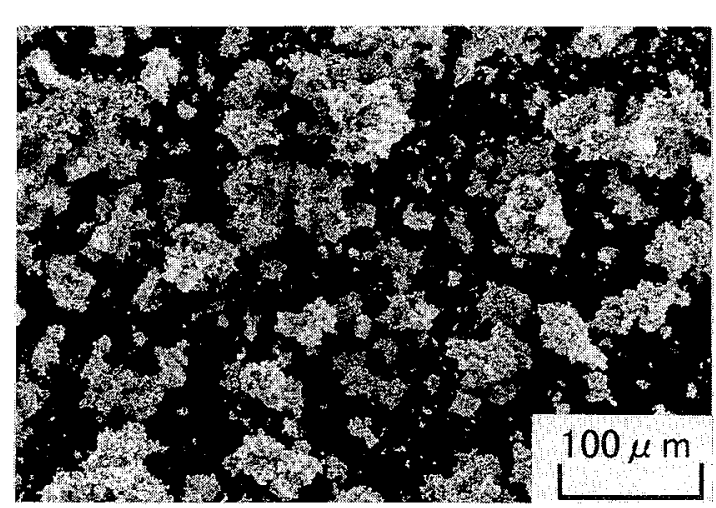

(b)

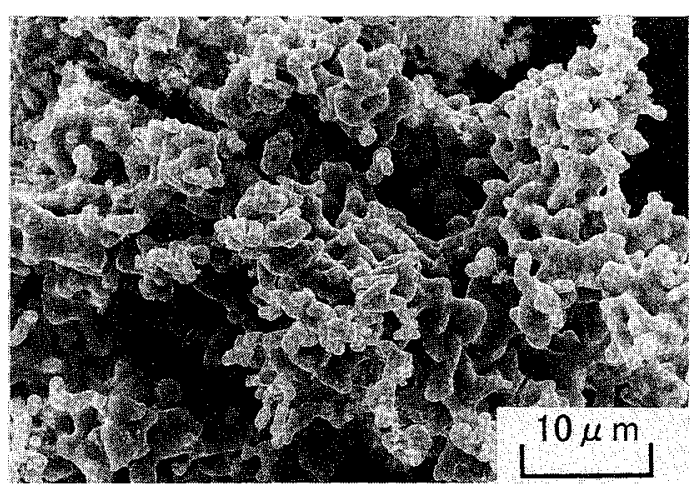

Fig. 5 Scanning electron micrograph of titanium powder obtained in a dish (exp. \#B).
実験 (exp. \#A)では，溶融塩の液面付近から多くの析出した 粉末状チタンが回収できた。これは， $\mathrm{DyCl}_{2}, \mathrm{DyCl}_{3}$ ならび にチタンの密度が，例光ば室温において，それぞれ， $\rho_{\mathrm{DyCl}_{2}}$ $=5.0, \rho_{\mathrm{DyCl}_{3}}=3.6, \rho_{\mathrm{Ti}_{\mathrm{i}}}=4.5 \mathrm{Mg} / \mathrm{m}^{3}$ であることから年想でき るように，実験 (exp. \#A)では，反応終了後も溶融程はほぼ $\mathrm{DyCl}_{2}$ であり，これよりも密度の小さいチタンが液面付近に 集をったことに起因すると考光られる。

本実験で得られた粉末状ヂンの代表的な形熊を示す電子 顕微鏡写真を Fig. 5 に示す.

生成した粉末状チタンは，各々が数十ミクロン程度の大き さであるが，それぞれの粒は，Fig. 5(b)K認められるよ5

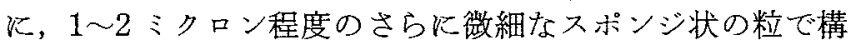
成されていた。このような数ミクロン程度の微視的な形態自 体は，従来のクロール法ならびに前報(10)(12)で示したLREMRにより生成した塊状のチタンでる認められた。

\section{V. 考察}

\section{1. ハライド熱還元法によるチタンの製造}

本研究の実験結果は，金属ではなく「ハライド塩を還元剤 として用いチタン塩化物原料を還元しチタンを得る」といら 新しい考方方の妥当性を実証するとともに， $\mathrm{DyCl}_{2}$ により $\mathrm{TiCl}_{4}$ の還元が可能ですり，乙かもイオン性融体の物性を利 用することによって生成チタンを反応容器壁炕固着させず

(a)

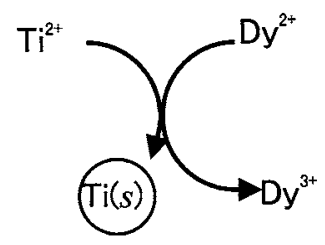

(b)

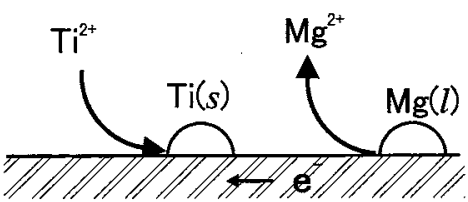

(c)

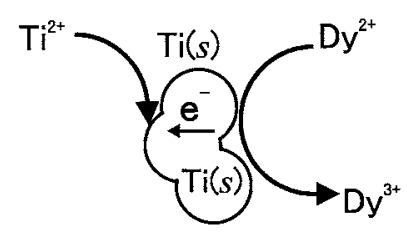

Fig. 6 The reaction mechanism of reduction of $\mathrm{TiCl}_{4}$ in molten salt.

(a) Homogeneous reaction during halidothermic reduction of $\mathrm{TiCl}_{4}$ by $\mathrm{DyCl}_{2}$.

(b) LR-EMR on the reactor wall during magnesiothermic reduction of $\mathrm{TiCl}_{4}$.

(c) Local LR-EMR on the titanium particle in molten salt during halidothemic reduction of $\mathrm{TiCl}_{4}$ by $\mathrm{DyCl}_{2}$. 
に，粉末状のまま回收でさることを明膫に示している．これ は本研究で行った実験条件下では，Fig. 6(a)k例として示 すように，溶融塩中に還元剤である $\mathrm{Dy}^{2+}$ が分散し，汪洼均 一反応の条件でチタン塩化物の還元反応が進行すると考えれ ば説明可能である。

一方，クロール法によって生成するチタンはスポンジ状の 塊であり反応容器壁に固着する傾向があるが(5)，これは， $\mathrm{MgCl}_{2}$ 中K金属マグネシウムが汪とんど溶解しないため, チタンの邆元反応は主にFig. 6(b)に示すょらな反応容器壁 および生成した金属チタンを導電体とする LR-EMRにより 生成し, 反応容器壁に固着し塊状になると考学られるためで 方る(10)(11)，本研究の上5に還元剤が溶融塩全体に分散した 場合では，反応容器壁を電子の移動経路とした還元反応は， クロール法に比べて生で難いが，反応浴とのものに電子后導 性がない限り局所的な LR-EMRが起こりらる。例光ば, Fig. 6(a)の反応で溶融塩中下生成した粉末状チタン自身は 良好な導電体であり，Fig. 6(c)に模式的に示すように，こ れを介した電子の移動により還元反応が進行する。これが， Fig. 5(b)K示すように, 得られた粉末状チタンに和ける数 ミクロン程度の微視的形態が LR-EMRにより生成されるチ タンと類似する要因と思われる. また， $\mathrm{TiCl}_{4}$ 供給管に付着 して得られたチタンが，塊状のチタンであった原因は，Fig. 6(b)に示すようにLR-EMRに上る供給管を介した電子供給 でチタンの成長が進行したためと考劣れば，容易に説明可能 である。

\section{2. $\mathrm{DyCl}_{2}$ 存在下でのチタン中の酸素不純物}

金属ヂタンは酸素と親和力が強く，クロール法に括ける $\mathrm{Mg} / \mathrm{MgO}$ 平衡では，平衡論的にチタン中の酸素を十分に取 り除汀ない。しかし，一般的に希土類塩化物は酸素との親和 力が非常に強く, 塩化物の共存下ではオキシクロライドを形 成する傾向が強い(24)。そこで, $\mathrm{DyOCl}$ の熱力学的安定性を 評価し、チタン塩化物の $\mathrm{DyCl}_{2}$ 還元に括けるチタン中の酸 素の平衡論的な除去限界を検討した結果について述べる．計 算に用いた熱力学データを Table 5 にをとめて示す。

$\mathrm{DyCl}_{2}$ (1)の生成の Gibbs ェネルギ一变化は，分解電生測 定から得られた值を使用した. DyOCl(s)の生成の Gibbs エ ネルギー変化は， $\Delta H_{\mathrm{DyOCl}, 298^{\circ}}^{\mathrm{f}}\left(-987 \mathrm{~kJ} / \mathrm{mol}^{(26)}\right)$ を用い，か つ LaOCl, NdOCl, ならびに $\mathrm{GdOCl} の \mathrm{Gibbs}$ エネギ一関 数 (Agef)が $1073 \mathrm{~K}$ に捈いて注注同一(それぞれ，-181，

Table 5 Summary of the standard Gibbs energy of reactions at $1073 \mathrm{~K}, \Delta G_{f}^{\circ}$, used in this study.

\begin{tabular}{lcl}
\hline \hline \multicolumn{1}{c}{ Reactions } & $\Delta G_{\mathrm{f}}^{\circ} / \mathrm{kJ} \cdot \mathrm{mol}^{-1}$ & \multicolumn{1}{c}{ Note } \\
\hline $\mathrm{Dy}(\mathrm{s})+3 / 2 \mathrm{Cl}_{2}(\mathrm{~g})=\mathrm{DyCl}_{3}(\mathrm{l})$ & -733 & $(14)$ \\
$\mathrm{Dy}(\mathrm{s})+\mathrm{Cl}_{2}(\mathrm{~g})=\mathrm{DyCl}_{2}(\mathrm{l})$ & -502 & $(23)$ \\
$\mathrm{Dy}(\mathrm{s})+1 / 2 \mathrm{O}_{2}(\mathrm{~g})+1 / 2 \mathrm{Cl}_{2}(\mathrm{~g})$ & -793 & estimated \\
$=\mathrm{DyOCl}(\mathrm{s})$ & -484 & $(14)$ \\
$\mathrm{Mg}(1)+1 / 2 \mathrm{O}_{2}(\mathrm{~g})=\mathrm{MgO}(\mathrm{s})$ & -495 & extrapolated $(25)$ \\
$1 / 2 \mathrm{O}_{2}(\mathrm{~g})=\underline{\mathrm{O}}(\mathrm{in} \alpha \mathrm{Ti}, 1$ mass$\%$ std.) & & \\
\hline
\end{tabular}

-184,ならびに-181 J/K. $\left.\mathrm{mol}^{-1}\right)^{(14) て ゙ あ る こ と か ら ， ~}$ DyOCl の $\Delta$ gefをー181 J/K. $\mathrm{mol}^{-1}$ として算出した. Table 5 に示すようにDyOC1の生成の標準 Gibbs エネルギ一は $1073 \mathrm{~K}$ に括いてー793 kJ/molであり，DyOClは極めて安定 な化学種と考えられる. 一方, 著者らの知る限り $\mathrm{DyCl}_{2}$ な どの塩化物溶融塩に対するDyOC1 の溶解度の実測値は報告 されていないようであるが, $\mathrm{REOCl}$ の希土類塩化物 $\left(\mathrm{RECl}_{3}\right.$ $(\mathrm{RE}=\mathrm{La}, \mathrm{Nd}, \mathrm{Sm}))$ への溶解度は $\mathrm{RECl}_{3}$ の融点直上で 18〜 $30 \mathrm{~mol} \% \mathrm{REOCl}$ と大をく(27),さらに $1073 \mathrm{~K}$ と打いて $\mathrm{MgCl}_{2}$ 単塩に $\mathrm{NdOCl}$ は $40 \mathrm{~mol} \%$ 以上溶解するとの報告 ${ }^{(28)}$ がある、したがって，DyOCl の $\mathrm{DyCl}_{2}$ あるい惊 $\mathrm{MgCl}_{2}$ など を含さ塩化物系溶融塩への溶解度は比較的大きいことが予想 される。

本研究でも，一部の実験で塩相のリーチング残渣から， $\mathrm{DyOCl}$ が粉末状チタンに混入している例が確認されている が，これは上記の熱力学データと矛盾しない。したがっ て，ジスプロシウム塩化物共存下では系内の酸素不純物の多 くは溶融塩相に存在している可能性が高いので, $\mathrm{DyCl}_{2}$ を使 ったハライド熱還元法によって得られる粉末状チタン中の不 純物酸素濃度は，クロール法により得られるチタンに比べ低 い可能性がある。そこで，式(5)に示す平衡を考光，千タ ソ中の不純物酸素の計算をTable 5 のデータを使用して式 (6)により試みた。

$$
\begin{aligned}
& 2 \mathrm{DyCl}_{2}+\underline{\mathrm{O}}_{\text {in } \alpha \mathrm{Ti}}=\mathrm{DyCl}_{3}+\mathrm{DyOCl} \\
& \log [\% \mathrm{O}]=-1.29+\log \left(a_{\mathrm{DyCl}_{3}} / a_{\mathrm{DyCl}_{2}}^{2}\right)+\log a_{\mathrm{DyOCl}}
\end{aligned}
$$

本研究で行った $\mathrm{DyCl}_{2}$ 過剩雲囲気下では， $a_{\mathrm{DyCl}_{3}}<a_{\mathrm{DyCl}_{2}}$ と 考党て良いので, DyOCl が溶融塩に大さく溶解度を持つと して DyOCl の活量を，例えば0.01と仮定すれば式(6)によ り, チタン中の平衡酸素濃度は $5 \mathrm{ppm}$ 以下 $\left(\log \left(p_{\mathrm{O}_{2}}\right)=-55\right.$ 以下)と求めることができる。ここで $a_{1}$ 特よび $p_{1}$ はそれぞれ 純物質 i 括よび $1 \mathrm{~atm}(101325 \mathrm{~Pa})$ のガス iを標準状態とし た活量とする。

一方で, $\mathrm{Mg} / \mathrm{MgO}$ 平衡下では，チタン中に固溶している 酸素の除去限界は次式で与光られる。

$$
\begin{aligned}
& \mathrm{Mg}+\underline{\mathrm{O}}_{\text {in } \alpha \mathrm{Ti}}=\mathrm{MgO} \\
& \log [\% \mathrm{O}]=0.51+\log a_{\mathrm{MgO}} \quad[1073 \mathrm{~K}]
\end{aligned}
$$

ここで, $\mathrm{MgO} の$ 活量 $\left(a_{\mathrm{MgO}}\right)$ を $\mathrm{DyOCl}$ の場合と同様に 0.01 とした場合，これと平衡するチタン中の酸素濃度は約 $300 \mathrm{ppm}\left(\log \left(p_{\mathrm{O}_{2}}\right)=-51\right)$ となる.この熱力学的検討結果 は，クロール法の場合に比へ $\mathrm{DyCl}_{2}$ 還元ではチタン中の平 衡酸素濃度はかなり低く，ハライド熱還元法は反応終了後の チタン回収時に溶融塩と金属チタンを効果的に分離さえでき れば，酸素濃度の低い粉末状チタンを直接製造できる可能性 を示唆しており極めて興味深い。

\section{3. 反応媒体塩としての $\mathrm{DyCl}_{2} / \mathrm{DyCl}_{3}$}

本研究では還元用として，工業的に一般的ではない $\mathrm{DyCl}_{2}$ を用いたが，Fig.1に示す $\mathrm{Dy}^{2+} / \mathrm{Dy}^{3+}$ の酸化還元電位と 


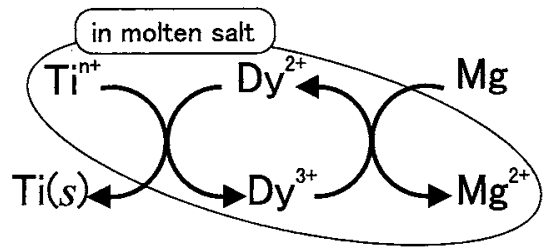

Fig. 7 Schematic diagram of magnesiothermic reduction of $\mathrm{Ti}^{\mathrm{n}+}$ utilizing $\mathrm{Dy}^{2+} / \mathrm{Dy}^{3+}$ reaction mediate in molten salt.

$\mathrm{Mg} / \mathrm{Mg}^{2+}$ の酸化還元電位との関係からも容易に推察できる よ5飞 $\mathrm{Dy}^{3+}$ は次式に示す反応によって金属マグネシウムに より $\mathrm{Dy}^{2+}$ に再生可能である。

$$
\mathrm{Mg}(1)+2 \mathrm{Dy}^{3+} \longrightarrow \mathrm{Mg}^{2+}+2 \mathrm{Dy}^{2+}
$$

また， $\mathrm{DyCl}_{2}$ ならびに $\mathrm{DyCl}_{3}$ は実験温度に执いて，全率溶 解 ${ }^{(29)}$ でり，Dy $2+$ Kるチタン塩化物の還元反応ならびK 反応生成物 $\mathrm{Dy}^{3+}$ のマグネシウムによる再還元反応は，金属 マグネシウムが共存する溶融塩中で同時進行可能であり，こ れらの総括反応性式(10)となる。

$$
\mathrm{Ti}^{4+}+2 \mathrm{Mg}(\mathrm{l}) \longrightarrow \mathrm{Ti}(\mathrm{s})+2 \mathrm{Mg}^{2+}
$$

この反応は，クロール法に特ける $\mathrm{TiCl}_{4}$ のマグネシウム還元 反応と見かけ上，同一でめり，還元剤として働く $\mathrm{DyCl}_{2}$ の 消耗はなくなり， $\mathrm{DyCl}_{x}$ は反応媒体塩として機能することを 示唆している。このよらな条件下では，Fig.7炡す上ら にマグネシウム還元でも, 反応容器壁ではなく溶融塩中でチ タン塩化物の還元反応を進行させることが可能であり，しか も反応生成物は生成粉末チタン以外，すべて融体であるた め, 粉末状チタンの反応容器からの連続的な取り出しが容易 になるすのと考えられる。また，還元力を有する反応媒体塩 を介して金属熱還元反応を行らといった手法は著者らの知る 限り過去に報告されて呿らず，今後の発展が期待される。

\section{V. 結論}

金属マグネシウムではなく $\mathrm{DyCl}_{2}$ を還元剤として用い， $\mathrm{TiCl}_{4}$ を繯元する新しい手法を考案し, 効果的に粉木状子タ ンを製造できる可能性を実証した，本法は，反応生成物であ る $\mathrm{DyCl}_{3}$ が金属マグネシウムによって再生可能であり，乙 か子還元反応は融体中で進行し, 生成する粉末状チタン以外 はすべて融体なので, 反店容吠ら生成チタンを草続的に取 り出すプロセスの開発も可能と考方られ，粉末状チタンの連 続生産法への応用が期待できる，具体的に得られた知見を列 記すると以下の通りである。

(1) $\mathrm{DyCl}_{2}$ は $1073 \mathrm{~K}$ に打いて $\mathrm{MgCl}_{2}$ による金属ジスプ ロシウム睘元で合成可能であることを実験的火確認した。

(2) $1073 \mathrm{~K}$ に陉いて $\mathrm{DyCl}_{2}$ 溶融塩単浴もしくはこれを 10 $\mathrm{mol} \%$ 以上含む溶融塩中に $\mathrm{TiCl}_{4}$ を供給した結果，粉末状千 タンが得られることを確認した。
（3）本研究で実証された新しい手法は，クロール法に比べ 反応容器壁へのチタンの固着が低減できるのみではなく，生 成したチタンの酸素濃度もクロール法で作製したスポンジチ タンの酸素濃度より低くできる可能性が熱力学的検討によっ て示された。

本実験を行うに際し，有意義な議論を賜った東北大学， 梅津良昭教授，葛西栄輝助教授，佐藤 譲助教授ならびに(有) NKR 二上 萝氏飞深く感謝いたします。また，試料の提供 它頂いた秝住金モりュープ山中輝雄氏，海老澤幸弘氏に深 く感謝致します。

\section{文献}

(1) C. K. Gupta: Int. Met. Rev., 29(1984), 405.

(2) F. H. Hayes, H. B. Bomberger, F. H. Froes, L. Kaufman and H. M. Burte: J. Metals, 36(6) (1984), 70.

(3) W. Kroll: Z. Anorg. Allg. Chem., 234(1937), 42.

(4) W. Kroll: Trans. Electrochem. Soc., 78(1940), 35.

(5) 森山徐一郎 : 京都大学水矅会誌, 22 (1995), 335.

（6）佐藤一裕，木村悦治：資源素材，105(1989)，623.

（7）小笠原忠司 : チタソ, 43(1995)，261.

（8）白石博章, 有本伸弘, 森 盛: チタニウム・ジルコニウム, 42(1994), 252

（9）深澤英一，河野通晴：チタニウム・ジルコニウム，42(1994)， 249.

（10）宇田哲也，岡部 徹，葛西栄輝，早稲田嘉夫：日本金属学会 誌, 61 (1997), 602.

（11）岡部徹，宇田哲也，葛西栄輝，早稲田嘉夫：日本金属学会 誌, 61(1997), 610 .

（12）宇田哲也, 岡部徹, 早稲田嘉夫：日本金属学会誌, 62(1998), 76.

(13）岡部皦, 宇田哲也：東北大学素材工学研究所量報, 53(1997), 1 .

(14) I. Barin: Thermochemical Data of Pure Substances, VCH, Weinheim, (1989).

(15) O. G. Polyachenok and G. I. Novikov: Russ. J. Inorg. Chem., 8(1963), 816.

(16) D. A. Johnson: J. Chem. Soc(A), (1969), 2578.

(17) L. R. Morss and H. O. Haug: J. Chem. Thermodynamics, 5(1973), 513.

(18) L. R. Morss and J. A. Fahey: Proc. 12th Rare Earth Res. Conf., 1(1976), 443

(19) L. R. Morss and M. C. McCue: Inorg. Chem., 14 (1975), 1624.

(20) V. F. Goryushkin: Russ. J. Phys. Chem., 68(1994), 1727.

(21) V. F. Goryushkin: Russ. J. Inorg. Chem., 41(1996), 538.

(22) G. Meyer: Chem. Rev., 88(1988), 93.

(23) 宇田哲也, 岡部 徹, 早稲田嘉夫：日本金属学会春期大会講 演概要, (1998), 382. (T. Uda, T. H. Okabe, Y. Waseda, K. T. Jacob: J. Alloys. Compound, Submitted.)

(24) J. D. Corbett, J. D. Smith and E. Garcia: J. Less. Common. Metals, 115(1986), 343.

(25) S. Miyazaki, T. Oishi and K. Ono: Proc. 5th. Int. Conf. Titan., (1984), 2657.

(26) D. D. Wagman, W. H. Evans, V. B. Parker, R. H. Schumm, I. Halow, S. M. Bailey, K. L. Churney and R. L. Nuttall: J. Phys. Chem. Ref. Data, 11(1982).

(27) E. M. Levin, C. R. Robbins and H. F. McMurdie: Phase diagrams for ceramists vol.1, Am. Ceramic. Soc, Ohio, (1964).

(28) P. G. Permyakov, B. G. Korshunov and V. A. Krokhin: Russ. J. Inorg.Chem., 20 (1975), 1096.

(29) J. D. Corbett and B. McCollum: Inog. Chem., 5(1966), 938. 